\title{
SEKSUALITAS PEREMPUAN BALI DALAM HEGEMONI KASTA: KAJIAN KRITIK SASTRA FEMINIS PADA DUA NOVEL KARANGAN OKA RUSMINI
}

\author{
Ida Ayu Made Darmayanti \\ Pendidikan Bahasa Dan Sastra Indonesia, Fakultas Bahasa dan Seni \\ Universitas Pendidikan Ganesha Singaraja, Indonesia
}

email: idaayumadedarmayanti@yahoo.com

\begin{abstract}
Abstrak
Banyak konflik internal yang terjadi di Bali. Konflik yang paling sering muncul hingga kini adalah konflik kasta. Berdasarkan data yang diperoleh, di berbagai kabupaten/kota di Bali, masih terjadi konflik akibat perbedaan kasta, terutama menimpa kaum perempuan. Beberapa contoh kasus yang ada adalah perempuan sudra yang menikah dengan laki-laki brahmana dilarang sembahyang di merajan kaum brahmana, perempuan brahmana yang menikah dengan laki-laki sudra dianjurkan menggugurkan kandungan ketika hamil, dan perempuan dilarang menyembah orang tua. Dalam pandangan feminis, kasus ini sudah mengerdilkan perempuan, bahkan membunuh kebebasannya sebagai manusia, padahal konvensi internasional tentang perempuan melarang jika terjadi pendiskriminasian terhadap perempuan. Diskriminasi terhadap perempuan akibat kasta ini, terangkat dalam kesusastraan Indonesia, yakni novel Tarian Bumi dan Kenanga. Novel ini memiliki kedudukan yang penting dalam kesusastraan Indonesia berkat suarasuara pemberontakan yang disampaikan pengarangnya untuk melakukan dekonstruksi terhadap pandangan patriarkhi. Sebagai akibatnya, novel ini paling banyak dibaca oleh masyarakat dan dijadikan sebagai bahan perkuliahan hingga di luar negeri. Penelitian deskriptif ini bertujuan mendeskripsikan seksualitas perempuan Bali dalam hegemoni kasta pada dua novel tersebut, mendeskripsikan pergerakan perempuan Bali dalam hegemoni kasta, dan mendeskripsikan peristiwa-peristiwa yang melingkupi novel tersebut. Penelitian ini menggunakan rancangan deskriptif kualitatif. Data dianalisis menggunakan teori triangulasi. Hasil penelitian menunjukkan bahwa perempuan Bali mengalami dominasi secara seksualitas oleh laki-laki Bali.
\end{abstract}

Kata kunci: seksualitas, perempuan, kasta, sastra feminis, oka rusmini

\begin{abstract}
Many internal conflicts that occurred in Bali. Conflicts most often arise until now is a caste conflict. Based on the data obtained, in different districts / cities in Bali is still a conflict due to caste differences, mainly affecting women. Some examples of cases there is a Sudra woman who married the man brahmin merajan banned prayer in the brahmin, brahmin women who marry men Sudra recommended an abortion when pregnant, women are prohibited from worshiping parents. In the feminist view, this case is dwarfed women, even killing his freedom as a human being, but an international convention on banning women in case of discrimination
\end{abstract}


against women. Discrimination against women due to this caste, raised in Indonesian literature, the novel Tarian Bumi and the novel Kenanga. This novel has an important position in Indonesian literature to the voices of the uprising that was delivered to the author to do the deconstruction of patriarchal views. As a result, the most widely read novel by the public and used as lecture material up abroad. This descriptive study aimed to describe female sexuality in the Balinese caste hegemony in the two novels, to describe bali women's movement in the caste hegemony, and describes the events surrounding the novel. The results showed that female sexuality Bali discriminated against by men of Bali. Discrimination in choosing a husband or expression. All the Bali female sexuality behavior is governed by an agreement Balinese men.

Key words : sexuality, women, caste, feminist literature, oka rusmini

\section{PENDAHULUAN}

Bali sangat menarik untuk dikaji. Kemenarikannya itu dapat ditinjau dari aspek spiritual/ritual, adat istiadat, budaya, seni, termasuk masyarakat (sosial) yang sangat berhubungan dengan adat atau budayanya.

Dari aspek hubungan manusia mengonstruksi sebuah budaya, masyarakat Bali mengusung pemikiranpemikiran yang arif atau memakai kearifan lokal-kearifan lokal (local genius). Beberapa contoh kearifan lokal yang masih kental diusung di Bali, antara lain konsep Menyama Braya, Salulung Sabayantaka, Tat Twam Asi, dan Tri Hita Karana (Sua, 2006: 13). Masyarakat Bali pun sangat tentram dengan adanya kearifan lokal di tengah budayanya sendiri.

Walaupun Bali mengusung kearifan lokal-kearifan lokal seperti itu, masyarakat Bali tidak terlepas dari konflik internal. Konflik internal merupakan konflik yang muncul dari dalam komunitas (masyarakat) Bali itu sendiri. Konflik yang paling klasik adalah konflik kasta.

Banyak orang di Bali mengatakan bahwa di Bali kasta memang tidak dikenal, yang ada hanyalah catur warna. Walaupun demikian, polemik yang berkepanjangan masih terjadi hingga sekarang (masa modern) di Bali. Bhagawan Dwija (2004) pernah menyampaikan pernyataan mengenai eksistensi kasta di Bali yang bersifat negatif dan bersifat konflik ketika menjawab pertanyaan umat dalam sebuah situs: http://shastras.org/ Shastras Balinese-)2.htm

"caste in that age was common. But the negative side is that the caste system was not formally applicable in goverment, old equal participant. Over time, althought caste system was not formally applicable in goverment, old traditions among Hindus has led to rising conflict and separated people into two major groups: the reformist and that status quo. Parisada Hindu Dharma Indonesia (PHDI) has also broken in two groups mentioned above"

Konflik kasta yang masih kental sampai sekarang ini adalah masalah pemosisian perempuan terhadap kebutuhan seksualitasnya dalam menentukan pasangan hidupnya.

Jurnal IImu Sosial dan Humaniora | 485 
Perempuan Bali dalam menentukan atau memilih pasangannya harus berdasarkan persetujuan laki-laki atau keluarga besarnya. Perempuan Bali sangat jarang diberikan membuat sebuah keputusan sendiri dalam menentukan pilihan hidupnya. Walaupuan itu ada, mereka (perempuan Bali) akan dibuang seumur hidup atau dibuang sampai ia memiliki anak (anak sebagai penyambung tali silahturahmi keluarga). Karepun (2005: 163) menuliskan bahwa perkawinan bukan saja dilarang, melainkan mempunyai konsekuensi hukum bagi pelakunya, baik bagi mempelai laki-laki maupun perempuan, dari hukuman penurunan kasta bagi mempelai perempuan sampai dengan hukuman buangan ke luar Bali bagi kedua mempelai dan bahkan sampai dihukum kejam labuh gni (upacara menjatuhkan diri ke api). Ini adalah salah satu bentuk kekerasan terhadap seksualitas perempuan di Bali. Salah satu contoh itu membuktikan pendapat Irawaty mengenai kekerasan terhadap perempuan. Irawati (2005) menyatakan secara tegas bahwa angka kekerasan terhadap perempuan berbasis gender masih sangat tinggi jumlahnya di negeri kita. Kekerasan terhadap perempuan adalah setiap tindakan yang berakibat kesengsaraan atau penderitaan-penderitaan pada perempuan secara fisik, seksual, atau psikologis, termasuk ancaman tindakan tertentu, pemaksaan atau perampasan kemerdekaan secara sewenangwenang, baik yang terjadi di depan umum maupun dalam lingkungan kehidupan pribadi (Tiwi, 2008: 4).

$$
\text { Berdasarkan data yang }
$$

dikumpulkan dengan teknik wawancara langsung yang bersifat terbuka dan intens dengan beberapa masyarakat Bali di Karangasem, Tabanan, Buleleng, Denpasar, Badung, Gianyar, dan Klungkung, diperolah data bentuk kasus pendiskriminasian seksualitas perempuan dalam hegemoni kasta yang ada di Bali (baca Tabel 01). Diskriminasi dalam konvensi CEDAW (dalam Vony Reyneta:2003: 11) memiliki konsep setiap pembedaan, pengucilan atau pembatasan yang dibuat atas dasar jenis kelamin, yang mempunyai pengaruh atau tujuan untuk mengurangi atau menghapuskan pengakuan, penikmatan, atau penggunaan hak-hak asasi manusia dan kebebasankebebasan pokok di bidang politik, ekonomi, sosial budaya, dan lain-lain oleh kaum perempuan, terlepas dari status perkawinan mereka, atas dasar persamaan antara laki-laki dan perempuan. Berdasarkan konsep, data dari wawancara dengan masyarakat Bali, dapat dibedakan menjadi tiga bagian bentuk kasus. Pertama, diskriminasi terhadap perempuan Bali secara seksualitas ditunjukkan oleh perilaku masyarakat yang berkasta tinggi terhadap masyarakat (perempuan) berkasta rendah. Kedua, diskriminasi terhadap perempuan Bali secara seksualitas ditunjukkan oleh perilaku pengasingan atau pengusiran oleh keluarga sudra. Ketiga, diskriminasi terhadap perempuan Bali secara seksualitas ditunjukkan oleh perilaku pengusiran atau pengaisngan perempuan berkasta oleh keluarga dari pihak laki-laki sudra. Ini disebabkan oleh paradigma masyarakat bahwa perempuan berkasta sering membawa aib atau sial kepada pihak laki-laki tidak berkasta (sudra).

Jurnal IImu Sosial dan Humaniora 486 
Data-data tersebut adalah gambaran mengenai hegemoni kasta yang masih membelenggu perempuan Bali pada sisi seksualitasnya yang tereksploitasi. Eksploitasi seksual terhadap perempuan menandakan pemerasan terhadap seks (jenis kelamin) perempuan, terutama untuk laki-laki atau perempuan yang memeras. Eksploitasi seksual terhadap perempuan menandakan pemanfaatan perempuan terutama seks yang berhubungan dengan persetubuhannya dengan laki-laki untuk keuntungan sendiri atau sebuah kelompok atau komunitas. Sebuah situs http://www. rahima.or.id memuat bahwa seksualitas jauh lebih luas daripada sekadar persoalan biologis, apalagi hanya urusan hubungan badan. Seksualitas mencakup seluruh kompleksitas emosi, perasaan, kepribadian, sikap dan bahkan watak sosial, berkaitan dengan perilaku dan orientasi atau preferensi seksual. Dalam KBBI (1989: 797) dinyatakan bahwa seksualitas sebagai ciri, sifat dan peranan, dorongan seks, atau kehidupan seks. Seksual berkenaan dengan seks (jenis kelamin). Seksual juga berkenaan dengan perkara persetubuhan (eksploitasi) antara lakilaki dan perempuan.

\begin{tabular}{cc} 
Adanya & \multicolumn{2}{c}{ diskriminasi } \\
perempuan Bali dalam kasta
\end{tabular} menandakan bahwa pemerintah di Bali masih belum berhasil menghapus segala bentuk diskriminasi di daerah. Ini sangat bertentangan dengan instruksi presiden untuk melaksanakan strategi pengarusutamaaan gender sebagai bagian pembangunan nasional (Sujardi, 2006: 35) yang telah diadopsi sejak tahun 2000 berdasarkan Inpres No. 9 Tahun 2000 (Silawati, 2006: 19).
Peristiwa-peristiwa kekerasan
terhadap seksualitas perempuan

mengilhami pengarang dalam karya sastranya. Hal ini tidak terlepas dari pandangan bahwa karya sastra terkonstruksi tidak dari kekosongan belaka, tetapi dari peristiwa-peristiwa di sekitar kehidupan pengarang. Ini adalah konsep teori mimesis. Karya sastra sebagai peniruan dari peristiwa yang terjadi di masyarakat. Bahkan tokohtokoh kritik feminis, seperti Kathe Millet, Simone de Beauvoir, Betty Fredan, dan Germain Greer memandang penting teks sastra. Hal itu dapat dijelaskan bahwa sastra sebagai produk kebudayaan merupakan ilustrasi seluruh kehidupan sosial (Tong, 1998). Umar Junus pun memandang teks sastra seperti hal yang demikian. Junus (1985: 5-6) menyatakan bahwa novel kelihatannya menghindarkan diri dari kegiatan hanya melaporkan. Novel mungkin hanya menghubungkan dengan satu peristiwa nyata belaka sehingga akan merasa ia benar-benar terjadi. Pernyataan yang tidak kalah penting untuk mendukung teori mimesis adalah pernyataan dari Sofia Kartika. Sofia (2003: 130) menyatakan bahwa realita masyarakat, terutama yang berkaitan dengan kehidupan perempuan yang tergambarkan dalam karya sastra, bisa jadi adalah hal-hal yag benar-benar terjadi di dunia nyata. Hal ini disebabkan oleh fungsi yang dimiliki karya sastra sebagai pengolah realita yang ada di masyarakat menjadi sebuah bahan refleksi diri. Dua contoh karya sastra yang dapat mewakili fungsi tersebut adalah novel Tarian Bumi dan Kenanga. Kedua novel itu merupakan karangan Oka Rusmini. Permasalahanpermasalahan yang diangkat oleh Oka

Jurnal IImu Sosial dan Humaniora | 487 
Rusmini sangat perlu dikaji sebagai upaya refleksi bagi masyarakat Bali agar menghargai atau menghapuskan bentuk-bentuk diskriminasi terhadap perempuan Bali.

Oka Rusmini merupakan pengarang Bali yang kepengarangannya diperhitungkan di tingkat Nasional dan dinilai sebagai penyair perempuan "pemberontak" terhadap gender. la acap menampakkan protes atas dominasi laki-laki dalam karya sastranya. Nuryana Asmaudi (2003) menyatakan bahwa Oka Rusmini sering menyuarakan harkat perempuan dalam dominasi patriarkis, terutama tentang kehidupan dan budaya Bali. Sebagai orang Bali (dan sebagai orang yang berkasta) Oka Rusmini sangat dekat dengan permasalahan-permasalahan perempuan Bali dan seksualitas perempuan akibat kasta yang menghegemoni. Dalam karya-karyanya, terutama novel Tarian Bumi dan Kenanga, peristiwa atau konflik mengenai dominasi laki-laki terhadap perempuan Bali, kasus-kasus tidak bebasnya perempuan dalam memilih pasangan karena adanya perbedaan kasta, sering mewarnai novel-novel tersebut. Novel Tarian Bumi menceritakan tentang perempuan berkasta: Ida Ayu Telaga; mengenai cara-cara berpikir orang Bali dalam mengambil keputusan untuk urusan jodoh dan perkawinan. Sementara itu, novel Kenanga lebih memfokuskan diri pada permasalahan kefanatikan kasta yang disandang oleh kaum Brahmana terhadap masyarakat sehingga menimbulkan konflik. Yasa (2005) melalui hasil penelitiannya menyimpulkan bahwa banyaknya masalah perkawinan atau percintaan karena perbedaan kasta yang diangkat Oka rusmini disebabkan oleh kehidupan Oka Rusmini di lingkungan Griya (hal ini semakin membuktikan adanya relasi antara pengalaman dan permasalahan di masyarakat tempat pengarang tinggal dengan karya sastra yang dibuat pengarang, Husna, 2001: 10).

Peristiwa-peristiwa itulah yang mewarnai kedua novel Oka Rusmini yang tidak terpisah dari pengalaman kepengarangannya sebagai orang Bali yang tinggal di Bali.

Peristiwa-peristiwa itu sangat perlu dikaji. Kajian ini akan dapat dijadikan bahan refleksi sehingga tidak muncul cauvinisme yang berlebihan terhadap kasta sekaligus menyelamatkan perempuan Bali dari hegemoni kasta yang masih kental di Bali.

Peristiwa-peristiwa yang mengonstruksi novel karya Oka Rusmini akan dianalisis menurut pandangan kritik sastra feminis. Kritik sastra feminis merupakan salah satu disiplin ilmu kritik sastra yang lahir sebagai respon atas berkembangluasnya feminisme di berbagai penjuru dunia. Moeliono, dkk. menyatakan bahwa feminism adalah gerakan kaum perempuan yang menuntut persamaan hak sepenuhnya antara kaum perempuan dan kaum lakilaki. Persamaan hak itu meliputi semua aspek kehidupan, baik dalam bidang politik, ekonomi, maupun sosial budaya (Djayanegara dalam Sugihastuti, 2005: 61). Feminism sebagai gerakan kaum perempuan untuk memperoleh otonomi atau kebebasan menentukan dirinya sendiri. Feminisme memperjuangkan dua hal yang selama ini tidak dimiliki kaum perempuan pada umumnya, yaitu persamaan derajat mereka dengan 
kaum laki-laki dan otonomi untuk menentukan yang baik bagi dirinya. Dalam banyak hal, perempuan tersubordinasi. Kedudukan perempuan di dalam masyarakat lebih rendah jika dibandingkan dengan posisi laki-laki. Mereka dianggap sebagai The second sex, warga kelas dua. Dalam pengambilan keputusan di banyak bidang, laki-laki saja yang hanya mendapat perhatian. Perempuan dipaksa untuk mengikuti mereka (Sugihastuti, 2005: vii). Annete Kolodny (dalam Sofyan Kartika, 2003) menyatakan bahwa kritik sastra feminis membeberkan perempuan menurut stereotif seksual, baik dalam kesusastraan maupun dalam kritik sastra. Feminisme dalam penelitian sastra dianggap sebagai upaya gerakan kesadaran terhadap pengabaian dan eksploitasi teradap perempuan dalam karya sastra.

Selama ini penelitian mengenai karya-karya Oka Rusmini sudah pernah dilakukan. I Nyoman Yasa pada tahun 2010 pernah meneliti mengenai alur Novel Tarian Bumi karya Oka Rusmini. Hasil penelitiannya adalah Novel Tarian Bumi memiliki alur majemuk (alur majumundur). Sementara itu, pada tahun 2010, I Nyoman Yasa pun pernah meneliti alur Novel Kenanga karya Oka Rusmini. Hasil penelitiannya bahwa alur novel Kenanga dikonstruksi oleh peristiwa-peristiwa yang saling berkaitan antara peristiwa-peristiwa yang satu dan yang lain. Cerita dikonstruksi oleh peristiwa masa kini, masa lalu dan masa yang akan datang. Dengan demikian, hasil peristiwa itu secara jelas menggambarkan bahwa novel Kenanga memiliki alur majemuk. Dua penelitian itu menekankan pada unsur intrinsik, yakni alur cerita novel, bukan permasalahan seksualitas perempuan di Bali. Sementara itu, pada tahun 2005, I Nyoman Adi Saputra meneliti karya sastra Oka Rusmini pada kumpulan cerpen "Sagra" dari aspek kehidupan sosial Bali ditinjau dari Sosiologi Sastra. Penelitian tersebut mengemukakan hasil penelitian bahwa aspek-aspek yang muncul pada kumpulan cerpen "Sagra" adalah aspek kekeluargaan, aspek kepercayaan, aspek ekonomi, aspek pendidikan, aspek politik dan aspek hukum. Aspek-aspek tersebut selalu muncul pada setiap cerpen Oka Rusmini, walaupun aspek kemunculannya tidak selalu sama. Sementara itu, Astini, dkk. pada tahun 2003 pernah meneliti perempuanperempuan dalam kultur patriarki Bali: Ideologi Gender dalam Novel Tarian Bumi. Penelitian ini tidak terfokus pada seksualitas perempuan Bali yag terhegemoni dalam kasta. Astini hanya menitikberatkan pada peranan perempuan dalam publisitasnya di Bali. Selain itu, Astini hanya meneliti novel Tarian Bumi saja, bukan dua novel karangan Oka Rusmini secara sekaligus. Atika (2000) pernah membicarakan bahwa novel perempuan Bali dalam Tarian Bumi sebagai perempuan yang menomorduakan dirinya. Dunia mereka adalah dunia yang terhegemoni (Adi Saputra, 2005: 2). Berdasarkan penelitian itu, peneliti yang mengangkat masalah seksualitas perempuan Bali dalam hegemoni kasta dengan menggunakan pendekatan kritik sastra feminis pada dua novel karangan Oka Rusmini belum ada.

Selain itu, ada beberapa peneliti yang mengangkat mengenai perempuan, tetapi penelitiannya tidak 
pada hegemoni kasta dan tidak pada novel Oka Rusmini. Contoh peneliti yang dapat dijadikan bukti adalah Sugihastuti, Kris Budiman, Endiriani Dwi Siswanti, dan Gadis Arivia. Sugihastuti melakukan studi kritik sastra feminis terhadap novel Siti Nurbaya. Sugihastuti menemukan bahwa perempuan dalam novel Siti Nurbaya diperlakukan berbeda dengan kaum laki-laki. Sementara itu, Kris Budiman (2003) meneliti novel Saman dan Larung karya Ayu Utami (sudah dibuat dalam bentuk artikel tentang Dari Saman ke Larung, Menemukan Kembali Sisa-Sisa Feminitas). Kris Budiman dalam artikelnya itu lebih menitikberatkan pada metafora seksualitas pada dua novel Ayu Utami, yakni Saman dan Larung. Kris Budiman menyoroti biseksualitas, heteroseksualitas dan oposisi biner antara laki-laki dan perempuan. Selain itu, Kris budiman dalam bukunya Pelacur dan Pengantin Adalah Saya (2005) mengungkap perlawanan terhadap ideologi patriarki alias fhalosentrisme dengan cukup jelas dan eksplisit pada beberapa bagian pada kedua novel Ayu Utami. Stereotif perempuan sebagai pihak yang pasif di hadapan laki-laki yang aktif digugat, antara lain dalam deskripsi hubungan seksual, vagina digambarkan sebagai bunga karnivora yang menjebak dan mengisap "binatang yang [...] bodoh dan tidak bertulang belakang, 'alias penis"” (dalam Bandel, 2006: 102). Endriani Dwi Siswanti (2003) meneliti tentang "Perempuan di Titik Nol, Perlawanan Perempuan Melawan Tatanan Konservatif". Endiriani memandang bahwa dalam novel Perempuan di Titik Nol, patriarkhi diposisikan sebagai akar penindasan perempuan. Gadis Arivia mengkritisi karya sastra Pramoedya Ananta Toer dan Toety Heraty, yakni tentang Calon Arang dan Calon Feminis: Kisah Pramoedya dan Kisah Toety Heraty. Gadis Arivia (2003: 80-81) menbandingkan mengenai tokoh Calon Arang dalam karya Pramoedya Ananta Toer dan Toety Heraty. Gadis menemukan bahwa Toety lebih memandang kisah Calon Arang lebih kompleks serta memberikan penjelasan latar belakang personal perempuan dihubungkan dengan persoalan budaya patriarkhi. Sementara itu, Pramoedya melihat kisah Calon Arang dalam dimensi hitam-putih, baik-jahat, atau menang-kalah.

Pramoedya menggunakan logika dikotomi yang sangat kental.

Bertolok pada hasil penelitian itu, penelitian tentang seksualitas perempuan Bali dalam hegemoni kasta dalam dua novel karangan Oka Rusmini belum pernah dilakukan. Oleh karena itu, penelitian yang mengangkat mengenai seksualitas perempuan Bali dalam hegemoni kasta dengan menggunakan pendekatan kritik sastra feminis pada dua novel karangan Oka Rusmini sangat perlu dilakukan.

Adapun rumusan masalah yang dapat dikemukakan adalah sebagai berikut: (1) Bagaimanakah seksualitas perempuan Bali dalam hegemoni kasta dalam dua novel karangan Oka Rusmini?; (2) bagaimanakah pergerakan perempuan Bali dalam hegemoni kasta pada dua novel karangan Oka Rusmini untuk memperjuangkan kebebasan sesksualitasnya?; dan apa peristiwaperistiwa yang melingkupi seksualitas

Jurnal IImu Sosial dan Humaniora 490 
perempuan Bali dalam hegemoni kasta pada dua novel karangan Oka Rusmini?

Ada beberapa tujuan penelitian ini. Pertama, penelitian ini bertujuan mendeskripsikan seksualitas perempuan Bali dalam hegemoni kasta dalam dua novel karangan Oka Rusmini. Kedua, penelitian ini bertujuan mendeskripsikan

pergerakan perempuan Bali dalam hegemoni kasta pada dua novel karangan Oka Rusmini untuk memperjuangkan kebebasan seksualitasnya. Terakhir, penelitian ini bertujuan mendeskripsikan peristiwaperistiwa yang melingkupi seksualitas perempuan Bali dalam hegemoni kasta pada dua novel karangan Oka Rusmini.

Ada beberapa manfaat penelitian ini. Yang pertama adalah manfaat teoretis. Secara teoretis, penelitian ini dapat digunakan sebagai bahan ajar oleh guru-guru (dosen) di skeolah/di perguruan tinggi dalam menanamkan sikap, pemikiran, dan perilaku siswa agar menghargai setiap perempuan (siswa laki-laki mengharagao atau tidak membedakan siswa perempuan), terutama siswa di Bali yang menganut sistem patriarkhi. Kedua, penelitian ini dapat memperkaya khazanah penelitian sastra, terutama karya sastra Oka Rusmini. Selain secara teoretis, penelitian ini juga memberikan manfaat secara praktis. Masyarakat akan dapat memnafaatkan penelitian ini dalam bersikap dan memperlakukan perempuan Bali, yang tidak membedakan atau mendiskriminassikan perempuan dalam kehidupan. Manfaat lainnya adalah memberikan sebuah "cermin" kepada masyarakat Bali yang masih kaku dalam menerapkan konsep kasta di Bali.

\section{METODE}

Desain yang dipilih untuk penelitian ini adalah deskriptif kualitatif. Desain ini digunakan untuk mendeskripsikan secara kritis seksualitas perempuan Bali dalam hegemoni kasta pada novel Tarian Bumi dan Kenanga karangan Oka Rusmini dengan menggunakan Studi Kritik Sastra Feminis. Hal ini akan memberikan gambaran terhadap masalah-masalah seksualitas perempuan Bali yang ada di dalam kedua novel tersebut.

Subjek penelitian ini adalah novel Tarian Bumi yang diterbitkan oleh Indonesiaterra pada tahuan 2000 dan novel Kenanga karangan Oka Rusmini yang diterbitkan oleh PT. Gramedia Widiasarana Indonesia pada tahun 2003, sedangkan objek penelitian yang diteliti mengenai seksualitas dalam novel Tarian Bumi dan Kenanga dengan menggunakan studi Kritik Sastra Feminis.

Teknik pengumpulan data terdiri atas pengenalan objek (diupayakan dengan membaca cermat dan sistematis isi cerita dalam novel Tarian Bumi dan Kenanga) dan penyeleksian data (untuk memudahkan proses kerja. Data yang diseleksi adalah data-data yang berhubungan langsung dengan permasalahan). Penelitian ini menggunakan instrumen penelitian berupa kartu data.

Data yang terkumpul dalam penelitian ini sebagian besar berwujud data kualitatif. Data ini dianalisis dengan melakukan berbagai kegiatan, yakni reduksi data, menyajikan, menafsirkan, dan menarik kesimpulan (Miles dna Huberman dalam Atmaja, 2006: 35).

Jurnal IImu Sosial dan Humaniora | 491 
HASIL DAN PEMBAHASAN

Seksualitas Perempuan Bali

Perempuan Bali secara seksual sangat didominasi oleh laki-laki. Secara seksual, perempuan Bali dilarang memilih pasangan hidupnya. Jika perempuan memiliki kasta brahmana, ia harus menikah dengan kaum laki-laki yang sederajat. Begitu pula, perempuan yang tidak berkasta harus menikah dengan laki-laki tidak berkasta. Dalam konteks ini, perempuan Bali secara seksual sangat didiskriminasikan oleh kaum laki-laki. Seksualitas Perempuan Bali dalam
Novel Tarian Bumi dan Kenanga

Seksualitas perempuan Bali dalam novel Tarian Bumi dan novel Kenanga sangat dieksploitasi. Eksploitasi ini dapat dicermati dalam bentuk diskriminasi dan dominasi laki-laki terhadap perempuan. Perempuan harus memilih pasangan sesuai dengan pilihan laki-laki. Perempuan tidak boleh berekspresi di ruang publik juga diatur oleh laki-laki. Dengan demikian, perempuan bali dalam novel Tarian Bumi dan Kenanga sangat didiskriminasi dan didominasi oleh lakilaki berkasta.

\section{Gerakan Perempuan Bali dalam Hegemoni Kasta}

Dominasi yang dilakukan oleh lakilaki terhadap perempuan Bali, memunculkan gerakan-gerakan perlawanan. Perlawanan-perlawanan yang dilakukan oleh perempuan Bali ada dalam bentuk pemilihan pasangan hidupnya. Perempuan yang berkasta memilih pasangannya yang tidak berkasta.

\section{Gerakan Perempuan Bali dalam Novel Tarian Bumi}

Pada novel Tarian Bumi perlawanan yang dilakukan oleh perempuan tampak pada perilaku lda Ayu Telaga yang menikah dengan I Wayan Sasmitha. Dekonstruksi adat dalam konteks itu terjadi. Perempuan berkasta yang harus menikah dengan laki-laki berkasta didekonstruksi melalui tokoh Ida Ayu Telalaga. Perempuan berkasta boleh menikah dengan laki-laki tidak berkasta.

\section{Gerakan Perempuan Bali dalam Novel Kenanga}

Pemberontakan atau perlawanan yang dilakukan perempuan Bali, yakni dengan menjalin hubungan pra-nikah. Hal ini tampak pada perilaku Ida Ayu Kenanga kepada Ida Bagus Bhuana. Penyimpangan perilaku tersebut dilakukan karena ibu kandung Kenanga sangat diskriminatif terhadap Kenanga. Tindakan diskriminatif itu tampak ketika lbu kandungnya menjodohkan kekasihnya untuk anak kesayangannya, Ida Ayu Kencana.

\section{Peristiwa-peristiwa yang Melingkupi Novel Tarian Bumi dan Kenanga}

Peristiwa merupakan peralihan dari keadaan yang satu ke keadaan lain (Jan Van Luxemburg, 1989: 150). Peristiwa juga sebagai unsur alur yang berupa kejadian yang penting atau kisahan pendek yang berhubungan dengan satu situasi. Dua novel karangan Oka Rusmini dibangun oleh beberapa peristiwa. Beberapa peristiwa dapat diuraikan sebagai berikut.

Jurnal IImu Sosial dan Humaniora 492 


\section{Peristiwa-peristiwa Melingkupi Novel Tarian Bumi}

Peristiwa yang membangun novel Tarian Bumi, antara lain peristiwa percintaan antara Ida Ayu Telaga dan I Wayan Sasmitha. Selain itu, konflikkonflik antarkasta, yang melibatkan keluarga berkasta dan tidak berkasta, yakni antara keluarga Ida Ayu Telaga dan keluarga I Wayan Sasmitha.

Peristiswa lainnya juga yang tampak adalah peristiwa upacara, terutama upacara patiwangi yang disampaikan oleh pengarang dalam ceritanya. Peristiwa ini tampak ketika Ida Ayu Telaga menikah dengan I Wayan Sasmitha.

\section{Peristiwa-peristiwa Melingkupi Novel Kenanga}

yang

Peristiwa yang melingkupi novel Kenanga adalah peristiwa sosial, pendidikan, adat istiadat, dan percintaan. Peristiwa sosial, contohnya, kehidupan Mahendra, Tuwe Gede, dan masyarakat di Cijantung, Jakarta yang keras dan mandiri (178-181) serta kehidupan Mahendra bersama temantemannya, yakni Trio Dekil dan kehidupann di Cijantung III yang serba sulit. Peristiwa percintaan, seperti percintaan antara Bhuana dan Kencana. Selain itu, kecemburuan Bhuana terhadap Kenanga (84-92). Bhuana juga menyampaikan bahwa anak hasil hubungan gelapnya masih hidup (8492). Peristiwa adat istiadat, seperti Dayu Galuh dan Luh Intan menghadiri upacara tiga bulanan (151-153).

\section{PENUTUP}

Perempuan Bali secara seksualitas sangat didominasi oleh lelaki Bali. Hal yang paling tampak adalah terbelenggunya perempuan Bali dalam menentukan pilihan dan menyampaikan suara-suaranya. Akibatnya, perempuan Bali melakukan pergerakan melawan atau memberontak dari tradisi dominasi laki-laki.

\section{DAFTAR PUSTAKA}

Aridus, 2006, 5 Februari. "Gejala Feminisme." Bali Post Hal.3.

Alwasilah, A. Chaedar. 2003. Pokoknya Kualitatif. Dasar-dasar Merancang dan Melakukan Penelitian Kualitatif. Jakarta: PT. Kiblat Buku Utama.

Arivia, Gadis. 2003. Calon Arang dan Calon Feminis: Kisah Pramodeya dan Toety Heraty. Jurnal Perempuan untuk pencerahan dan kesetaraan. Volume 30, hal. 80-81.

Asmaudi, Nuryana. 2003, 2 November. "Sajak-sajak kesaksian Oka Rusmini”. Bali Post, hal. 10.

Astini, dkk. 2003. Perempuanperempuan dalam Kultur Patriarki Bali: Ideologi Gender dalam Novel Tarian Bumi Karya Oka Rusmini (Laporan Penelitian). Singaraja: IKIP Negeri Singaraja.

Bandel, Katrin. 2006. Sastra, Perempuan, dan Seks. Yogyakarta: Jalasutra.

Budiman, Kris. 2003. Dari Saman ke larung, Menemukan Kembali Sisasia Feminitas. Jurnal Perempuan untuk Pencerahan dan Kesetaraan. Edisi 30, hal 7.

Dwija, Bhagawan. 2004. Caste in Bali: A Short

Story. 
http://www/shastras.Org. Diakses tanggal 23 April 2008.

Husna, Khtimatul, 2001, 18 November. “ Sagra”, bahasa perempuan Bali”. Bali Post, hlm. 10.

Irawaty, Diah. 2005. Yang khas dari masalah PRT Perempuan dan Pendampingannya. Jurnal Perempuan untuk Pencerahan dan Kesetaraan, Vol. 30.

Junur, Umar. 1985. Dari Peristiwa ke Imajinasi: Wajah Sastra dan Budaya Indonesia. Jakarta: PT. Gramedia.

Kartika, Sofia. 2003. Kritik Sastra Feminis; Sebuah Jalan Menuju Kesetaraan Melalui Dunia Sastra. Jurnal Perempuan untuk Pencerahan dan Kesetaraan, Vol 30.

Rusmini, Oka. 2000. Tarian Bumi. Magelang: Indoensia tera.

Rusmini, Oka. 2003. Kenanga. Jakarta: Grasindo.
Saputra, Adi. 2005. Aspek Kehidupan Sosial Bali dalam Kumpulan Cerpen Sagra Karya Oka Rusmini (Sebuah Telaah Sosiologi Sastra). Skripsi tidak diterbitkan.

Sugihastuti. 2005. Kritik Sastra Feminis: Teori dan Aplikasinya. Yogyakarta; Pustaka Pelajar.

Tim Penyusun. 1989. Kamus Besar Bahasa Indonesia. Jakarta: Balai Pustaka

Tong, Rosemarie Putnam. 1998. Feminis Thought: Pengantar Paling Komprehensif kepada aliran Utama Pemikiran Kritis. Yogyakarta: Jalasutra.

Yasa, I Nyoman. 2010. Alur Novel Kenanga Karya Oka Rusmini. Jurnal Prasi, Jurnal Bahasa, Seni, dan pengajrannya, Januari-Juni, Vol. 6, No. 11, ISSN 16936124.

---- 2010. Alur Novel Tarian Bumi Karya Oka Rusmini. Jurnal Lingua Didaktika, Jurnal Bahasa dan Pengajaran Bahasa, Vol. 3, No. 2, Juli 2010, ISSN 1979-0547. 